\title{
Dynamika zmian składu ciała zawodników kadry polskich pływaków w okresie miesięcznego zgrupowania poprzedzającego Mistrzostwa świata juniorów w Dubaju w 2013 roku
}

\section{Dynamics of changes body composition of polish national swimming team during the one month of training camp prior the junior World Championship in Dubai in 2013}

\author{
Żaneta Ciosek , Adam Drozd², Anna Lubkowska ${ }^{3}$ \\ 1 Samodzielna Pracownia Rehabilitacji Medycznej Pomorskiego Uniwersytetu Medycznego w Szczecinie \\ ul. Żołnierska 54, 71-210 Szczecin \\ Kierownik: dr n. med. Iwona Rotter \\ ${ }^{2}$ Studenckie Koło Naukowe przy Zakładzie Diagnostyki Funkcjonalnej i Medycyny Fizykalnej Pomorskiego Uniwersytetu Medycznego w Szczecinie \\ ul. Żołnierska 54, 71-210 Szczecin \\ Opiekun: dr hab. n. zdr., prof. PUM Anna Lubkowska
}

${ }^{3}$ Zakład Diagnostyki Funkcjonalnej i Medycyny Fizykalnej Pomorskiego Uniwersytetu Medycznego w Szczecinie

ul. Żołnierska 54, 71-210 Szczecin

Kierownik: dr hab. n. zdr., prof. PUM Anna Lubkowska

\section{SUMMARY}

Introduction: World Championship in swimming are the most prestigious competition, where many countries around the world takes part in it. To prepare for the highest level for this type of event, swimmers need to train in adequate training base. Currently, the best center in Poland is at the Floating Arena swimming pool in Szczecin.

The aim of this study was to analyze the impact training during start preparation period, on body mass composites.

Material and methods: For this study it was examined 14 swimmers, members of the Polish Junior National Team, who were during a training camp in Szczecin, for one month before main competition. Research consisted of 9 measurements of body composites, made by analyzer TANITA BC-420 MA. Method used was bioelectrical impedance analysis (BIA). Components taken under measurements are: body mass (BM), mean body fat (MBF),

\section{STRESZCZENIE}

Wstęp: Mistrzostwa świata w pływaniu należą do najbardziej prestiżowych zawodów sportowych. Biorą w nich udział zawodnicy wielu krajów z całego świata. Do przygotowania się na najwyższym poziomie na tego typu imprezy konieczna jest m.in. odpowiednia baza treningowa. Obecnie jednym z najlepszych ośrodków w Polsce spełniającym kryteria prowadzenia treningu pływaków jest kompleks Floating Arena w Szczecinie zawierający całą bazę urządzeń diagnostyczno-treningowych.

Celem badań była ocena zmian składu ciała pływaków w trakcie okresu bezpośredniego przygotowania startowego poprzedzającego mistrzostwa świata w pływaniu w 2013 r.

Materiał i metody: Badaniami objęto 14-osobową grupę zawodników w wieku 15-18 lat będących na zgrupowaniu kadry narodowej juniorów w Szczecinie. U każdego z uczestników badań przeprowadzono 9-krotną analizę składu ciała metodą bioimpedancji elektrycznej (Tanita BC-420 MA). Do analizy, jako główne, wykorzystano następujące dane: pomiar masy ciała fat free mass (FFM), muscle mass (MM), total body water (TBW), and body mass index (BMI).

Results: All results of the last day of measurements, showed decreasing tendency comparing to the first day of measurements. The statistically important changes were reported in BM, TBW and BMI components. In this 4 weeks start preparation period, all the results slightly decreased. This tendency is highly recommended in professional sports.

Conclusions: Research has shown that properly conducted training in the 4-week preparation starter, despite a decline in training loads characteristic of this period, along with a balanced diet, allows to maintain a stable body weight and the distribution of its components directly from participating in the competition, which is of great importance for athletic performance swimmers.

Key words: body composition, training dynamics.
(BM), zawartość tkanki tłuszczowej (MBF), wolną masę beztłuszczową (FFM), masę mięśniową (MM), całkowitą ilość wody w organizmie (TBW) oraz ciężar ciała (BMI).

Wyniki: W trakcie okresu przygotowania startowego odnotowano obniżenie wartości wybranych parametrów składu ciała względem wartości wyjściowej (na poziomie $\mathrm{p} \leq 0,05$ ) w odniesieniu do BM, BMI i TBW. Średnie obniżenie masy ciała wynosiło $1,1 \mathrm{~kg}$, co przełożyło się na obniżenie o 0,32 pkt wartości wskaźnika BMI badanych. Zmiany w kierunku obniżania się tych parametrów składu ciała są jak najbardziej prawidłowe i oczekiwane. Wnioski: Wyniki badań potwierdziły, że prawidłowo prowadzony trening w okresie 4-tygodniowego przygotowania startowego, pomimo spadku obciążeń treningowych charakterystycznych dla tego okresu, wraz ze zbilansowaną dietą, pozwolił na utrzymanie stabilnej masy ciała wraz z rozkładem jej komponentów bezpośrednio przed udziałem w zawodach, co miało znaczenie dla wyników sportowych pływaków.

Słowa kluczowe: komponenty ciała, trening pływacki. 


\section{WSTĘP}

Pływanie, jako forma ruchu, przemieszczania się sięga czasów starożytnych. Pierwsze wioski, osady były zakładane przy dużych zbiornikach wodnych. Dlatego umiejętność pływania stanowiła jeden z elementów ułatwiających życie. Starożytni Rzymianie twierdzili, że tylko mężczyźni posiadający zdolność pływania, mogą stać się wojownikami legionów. Natomiast Grecy pływanie uważali za niezbędny czynnik harmonijnego rozwoju ciała i ducha [1]. Obecnie pływanie jest nie tylko dyscypliną sportową, ale także doskonałą formą rehabilitacji. Pozwala znacząco redukować poziom napięcia mięśniowego związanego z ekspozycją na czynniki stresogenne w życiu codziennym. Trening pływacki pozytywnie wpływa na układ oddechowy i krążenia, a także na polepszenie tempa metabolizmu. Z punktu biomechaniki istotne jest odciążenie, jakie udaje się uzyskać przy prowadzeniu kinezyterapii w środowisku wodnym. Przy odpowiednio dobranych ćwiczeniach można znacząco podnosić wydolność fizyczną organizmu. Podczas gdy pływak znajduje się w wodzie, na jego ciało działają siły ciśnienia atmosferycznego, a także ciśnienia hydrostatycznego związane z poziomem zanurzenia. Im ciało znajduje się głębiej pod wodą, tym ciśnienie hydrostatyczne rośnie.

Mistrzostwa świata w pływaniu należą do cyklu zawodów najbardziej prestiżowych. Biorą w nich udział zawodnicy wielu krajów z całego świata. Jest to najważniejsza impreza sezonu. Zdobycie pierwszego miejsca w tych zawodach potwierdza najwyższą klasę zawodniczą w określonej kategorii wiekowej. Mistrzostwa świata są przeprowadzane na dwóch długościach pływalni: 25 m i 50 m. Zarówno na krótkim, jak i na długim basenie zawody odbywają się w cyklu 2-letnim, naprzemiennie. Od 2006 r. zaczęto również organizację Mistrzostw świata juniorów, także w cyklu 2-letnim.

Ostatnia edycja zawodów w kategorii juniorów miała miejsce w Dubaju 26-31 sierpnia 2013 r. W zawodach tych mogą wziąć udział zawodnicy poniżej 18. r.ż. Dla nich jest to sprawdzian przed wejściem w okres seniorski. Możliwość przygotowania się na najwyższym poziomie na tego typu imprezy wymaga, oprócz wiedzy i umiejętności trenera, zaangażowania zawodników, a także zaplecza w postaci bazy treningowej. Obecnie najlepszym miejscem do prowadzenia treningu pływackiego w Polsce jest obiekt Floating Arena w Szczecinie. Ośrodek powstał w 2010 r., a już w 2011 r. zostały przeprowadzone na nim Mistrzostwa Europy seniorów na krótkim basenie. Dysponując dwoma pływalniami (25 m i $50 \mathrm{~m}$ ) zlokalizowanymi w jednym obiekcie, wzorem ośrodków w USA i Australii, istnieje możliwość takiego zaplanowania treningu, aby dostarczyć w nim zróżnicowanych bodźców w każdym mikrocyklu [2].

Obecnie, poza przygotowaniem motorycznym, wytrzymałościowym, wynik sportowy uzależniony jest od wielu dodatkowych czynników. Wielu producentów prześciga się w uzyskiwaniu najlepszych parametrów związanych z opływowością projektowanych pływackich strojów startowych, jednak obecne przepisy ściśle tę kwestię regulują, zapewniając równość sprzętową dla każdego zawodnika. Należy więc zwrócić uwagę na inne aspekty mogące mieć wpływ na poprawę dynamiki pływania. Jednym z nich jest prawidłowe ustawienie ciała w wodzie. W nawiązaniu do badań przeprowadzonych przez Onoprijenkę [3], nawet najmniejsza zmiana ułożenia ciała powoduje znaczące różnice w wielkości oporu wody. Im ciało jest ułożone bardziej pionowo (nasilenie zgięciowego ustawienia stawów biodrowych, kolanowych, skokowych), tym opór wody jest większy. W przypadku, gdy utrzymanie opływowości ciała jest niewystarczająco dopracowane, zawodnik będzie musiał włożyć większy wydatek energetyczny, aby osiągnąć określony wynik czasowy. Kolejnym czynnikiem warunkującym osiąganie wyników jest zachowanie określonego poziomu zanurzenia. Im głębiej zanurzone ciało, tym większy opór niż w przypadku zawodnika leżącego wyżej na wodzie, co wiąże się z koniecznością wydatkowania dodatkowej energii na jego pokonanie [4]. Zmiana masy i procentowego udziału poszczególnych komponentów ciała jest czynnikiem bezpośrednio wpływającym zarówno na precyzję kontroli głębokości zanurzenia, utrzymania opływowości ciała oraz oporu, jaki ono stawia podczas pływania [5].

Celem badań prezentowanych w pracy było wykazanie, czy zawodnicy w trakcie bezpośredniego przygotowania startowego (BPS) są w stanie utrzymać stałe i prawidłowe wartości parametrów składu ciała przy zmianie obciążeń treningowych, typowych dla tego okresu.

\section{MATERIA $Ł$ I METODY}

Badania były wykonane w trakcie zgrupowania szkoleniowego kadry narodowej juniorów przygotowującego do startu na Mistrzostwach świata juniorów w Dubaju. Zgrupowanie miało miejsce w Szczecinie w dniach 24.07-24.08.2013 r. Treningi odbywały się na terenie pływalni olimpijskiej Floating Arena. Był to okres bezpośredniego przygotowania startowego, do realizacji którego wybrano model 6-tygodniowy z następującym systematyczne obniżaniem obciążeń treningowych, przy wzroście zadań o charakterze szybkościowym. Zmiany treningu następowały co tydzień. Wykonywane były dodatkowo ćwiczenia gimnastyki ogólnej na lądzie.

Badaniami objęto grupę składającą się z 14 zawodników 3 zawodniczek w wieku 15-16 lat (średnia wieku 15,6 lat) oraz 11 zawodników w wieku 17-18 lat (średnia wieku 17,3 lat). Zawodnicy ci reprezentowali różne kluby z całej Polski. Wszyscy zostali powołani do kadry narodowej na podstawie osiągnięcia minimum, wyznaczonego przez Polski Związek Pływacki podczas Mistrzostw Polski seniorów w Olsztynie (13-16.06.2013 r.), kwalifikującego ich na zawody w Dubaju. Stanowili oni grupę najlepszych zawodników w kraju wśród juniorów. W nawiązaniu do przepisów Światowej Organizacji Pływania (FINA), zawodnicy powołani na zawody byli w następującym przedziale wiekowym: zawodniczki -15-16 lat, zawodnicy - 17-18 lat.

Analizy składu ciała były wykonywane za pomocą analizatora składu ciała, z pomiarem tłuszczu trzewnego, marki TANITA model BC-420 MA. Aparat posiada certyfikat CE oraz spełnia wymagania dyrektywy MDD 93/42EEC w zakresie 
urządzeń medycznych. Aparat ten wykorzystuje metodę pomiaru impedancji (50 Hz), przy ułożeniu 4-elektrodowym. Badania przeprowadzono 9-krotnie, a częstotliwość pomiarów wynosiła 2 razy na tydzień. Każdorazowo badania były wykonane rano, na 15 min przed treningiem porannym, w cyklu 2 treningi/dzień. Zawodnicy byli wysuszeni, przez co niemodyfikowana była wartość impedancji $(\Omega)$. W związku z tym, że zawodnicy byli analizowani w treningowych strojach pływackich, przyjęto wagę startową na poziomie 0,00 kg. Wysokość ciała każdego zawodnika została wcześniej zmierzona z wykorzystaniem wzrostomierza wagi lekarskiej służącego do pomiaru wagi oraz wysokości ciała. Do analizy statystycznej jako główne dane wykorzystano pomiar masy ciała (BM), zawartość tkanki tłuszczowej (MBF), wolną masę beztłuszczową (FFM), masę mięśniową (MM), całkowitą ilość wody w organizmie (TBW) oraz ciężar ciała (BMI).

Analiza statystyczna została przeprowadzona w programie Statistica (wersja $10.0 \mathrm{pl}$ ). Zostały w niej przedstawione statystyki opisowe, takie jak: średnia ary tmetyczna, odchylenie standardowe, minimum, maksimum. Określono również poziom istotności różnic wyników z kolejno przeprowadzanych badań. Po przeprowadzeniu testu na normalność rozkładu badanych danych (Shapiro-Wilka) stwierdzono, iż większość parametrów miała rozkład odbiegający od normalnego. W związku z powyższym do porównania zmian wartości zastosowany został nieparametryczny test Wilcoxona.

\section{WYNIKI}

Oceniając średnie wartości poszczególnych parametrów dla całej grupy badanej, w trakcie 9 pomiarów można było zauważyć niewielkie zmiany w składzie ciała. W trakcie 2., 4., 5. i 7. pomiaru wszystkie wartości ulegały stopniowemu obniżeniu, natomiast przy pomiarze 3., 6. i 8. wykazano podwyższenie wartości niemal we wszystkich parametrach, po czym niewielka obniżka miała miejsce przy pomiarze 9. Wartości najniższe zostały osiągnięta w trakcie badania nr 7 (tab. 1).

TABELA 1. Wartości średnie £SD parametrów składu ciał zawodników uzyskane w kolejnych dniach przygotowania treningowego

\begin{tabular}{lccccccccc} 
& $\mathbf{1}$ & $\mathbf{2}$ & $\mathbf{3}$ & $\mathbf{4}$ & $\mathbf{5}$ & $\mathbf{6}$ & $\mathbf{7}$ & $\mathbf{8}$ & $\mathbf{9}$ \\
\hline BM & 76,1 & 75,6 & 76,0 & 75,3 & 75,2 & 76,1 & 75,1 & 75,8 & 75,5 \\
(kg) & $\pm 7,06$ & $\pm 7,01$ & $\pm 7,05$ & $\pm 6,98$ & $\pm 6,97$ & $\pm 7,06$ & $\pm 6,96$ & $\pm 7,03$ & $\pm 7,00$ \\
\hline MBF & 9,7 & 9,5 & 9,5 & 9,2 & 9,2 & 9,5 & 9,4 & 9,1 & 9,4 \\
(kg) & $\pm 4,96$ & $\pm 5,12$ & $\pm 5,12$ & $\pm 5,57$ & $\pm 5,57$ & $\pm 5,12$ & $\pm 5,21$ & $\pm 5,45$ & $\pm 5,21$ \\
\hline FFM & 66,4 & 66,1 & 66,4 & 66,1 & 65,9 & 66,6 & 65,7 & 66,6 & 66,1 \\
(kg) & $\pm 9,30$ & $\pm 9,24$ & $\pm 9,30$ & $\pm 9,24$ & $\pm 9,20$ & $\pm 9,34$ & $\pm 9,16$ & $\pm 9,34$ & $\pm 9,24$ \\
\hline MM & 63,1 & 62,8 & 63,1 & 62,8 & 62,7 & 63,3 & 62,4 & 63,3 & 62,8 \\
(kg) & $\pm 8,86$ & $\pm 8,81$ & $\pm 8,86$ & $\pm 8,81$ & $\pm 8,80$ & $\pm 8,89$ & $\pm 8,76$ & $\pm 8,89$ & $\pm 8,81$ \\
\hline TBW & 47,7 & 47,6 & 47,6 & 47,3 & 47,2 & 47,7 & 47,0 & 47,8 & 47,4 \\
(kg) & $\pm 6,35$ & $\pm 6,29$ & $\pm 6,29$ & $\pm 6,12$ & $\pm 6,06$ & $\pm 6,35$ & $\pm 5,94$ & $\pm 6,40$ & $\pm 6,18$ \\
\hline BMI & 22,1 & 22,0 & 22,1 & 21,9 & 21,9 & 22,1 & 21,8 & 22,1 & 22,0 \\
(pkt) & $\pm 1,13$ & $\pm 1,16$ & $\pm 1,13$ & $\pm 1,19$ & $\pm 1,19$ & $\pm 1,13$ & $\pm 1,22$ & $\pm 1,13$ & $\pm 1,16$
\end{tabular}

BM - pomiar masy ciała; MBF - zawartość tkanki tłuszczowej; FFM - wolna masa beztłuszczowa; MM - masa mięśniowa; TBW - całkowita ilość wody w organizmie; $\mathrm{BMI}$ - ciężar ciała
Analizując poszczególne parametry (tab. 2,3) całej grupy badanej, odnotowano, że największe zmiany zaszły w wartościach BM oraz BMI. Aż u 10 osób, co stanowi 71,4\% ogółu badanych; wartości te uległy poprawie z punktu widzenia założeń treningowych. Średnie obniżenie masy ciała wynosiło $1,1 \mathrm{~kg}$, co przełożyło się na obniżenie o 0,32 pkt wartości wskaźnika BMI badanych. Korzystne tendencje odnotowano także u 8 (57,1\%) osób dla MBF $(0,91 \mathrm{~kg})$ i TBW (0,81 kg), choć nie były one znamiennie statystyczne. Najmniejsza zmiana odnosiła się

TABELA 2. Indywidualne zmiany wartości analizowanych parametrów w trakcie okresu przygotowania startowego

\begin{tabular}{rcccccc} 
& BM \pm & MBF \pm & FFM \pm & TBW \pm & MM \pm & BMI \pm \\
\hline 1. & 1,7 & 1,5 & 0,2 & 0,2 & 0,2 & 0,5 \\
\hline 2. & $-0,9$ & 0,1 & -1 & $-0,7$ & $-1,0$ & $-0,3$ \\
\hline 3. & $-1,5$ & $-0,5$ & -1 & $-0,8$ & $-1,0$ & $-0,4$ \\
\hline 4. & $-1,7$ & $-0,7$ & -1 & $-0,7$ & $-1,0$ & $-0,5$ \\
\hline 5. & $-1,8$ & $-0,2$ & $-1,6$ & $-1,2$ & $-1,5$ & $-0,5$ \\
\hline 6. & 0,5 & 0,3 & 0,2 & 0,1 & 0,2 & $-0,1$ \\
\hline 7. & -1 & 0 & -1 & $-0,8$ & $-1,0$ & $-0,3$ \\
\hline 8. & 0,5 & 0,3 & 0,2 & 0,1 & 0,2 & 0,1 \\
\hline 9. & $-0,8$ & $-0,2$ & $-0,6$ & $-0,5$ & $-0,5$ & $-0,2$ \\
\hline 10. & $-1,1$ & $-3,9$ & 2,8 & $-0,5$ & 2,6 & $-0,3$ \\
\hline 11. & $-0,1$ & $-0,5$ & 0,4 & 0,3 & 0,3 & 0,0 \\
\hline 12. & $-1,1$ & 0,4 & $-1,5$ & $-1,3$ & $-1,4$ & $-0,3$ \\
\hline 13. & 0,2 & 0 & 0,2 & 0,3 & 0,2 & 0,1 \\
\hline 14. & -1 & $-1,3$ & 0,3 & 0,5 & 0,3 & $-0,3$ \\
\hline
\end{tabular}

BM - pomiar masy ciała; MBF - zawartość tkanki tłuszczowej; FFM - wolna masa beztłuszczowa; TBW - całkowita ilość wody w organizmie; MM - masa mięśniowa; BMI - ciężar ciała

Na szaro zostały oznaczone wyniki, które uległy obniżeniu względem pierwszego pomiaru.

TABELA 3. Zestawienie średnich $\pm S D$, minimum, maksimum oraz poziomów istotności poszczególnych wskaźników składu ciała pomiędzy pierwszym a ostatnim pomiarem w grupie badanej

\begin{tabular}{|c|c|c|c|}
\hline \multirow{2}{*}{ Grupy } & \multicolumn{3}{|c|}{$K+M, n=14, K=3, M=11$} \\
\hline & średnia $\pm S D$ & $\min$. & maks. \\
\hline BM1 & $76,09 \pm 7,06$ & 58,20 & 83,60 \\
\hline BM9 & $75,51 \pm 7,00$ & 58,7 & $\begin{array}{c}82,80 \\
{ }^{*} \text { vsBM1 }\end{array}$ \\
\hline MBF1 & $9,71 \pm 4,96$ & 4,40 & 23,90 \\
\hline MBF9 & $9,41 \pm 5,21$ & 4,60 & 25,00 \\
\hline FFM1 & $66,37 \pm 9,30$ & 45,20 & 78,60 \\
\hline FFM9 & $66,13 \pm 9,24$ & 45,40 & 77,10 \\
\hline MM1 & $63,08 \pm 8,86$ & 42,90 & 74,70 \\
\hline MM9 & $62,84 \pm 8,81$ & 43,10 & 73,30 \\
\hline TBW1 & $47,74 \pm 6,35$ & 33,10 & 54,70 \\
\hline TBW9 & $47,39 \pm 6,18$ & 33,20 & $\begin{array}{c}54,20 \\
\text { *vsTBW1 }\end{array}$ \\
\hline BMI1 & $22,14 \pm 1,13$ & 20,40 & 24,50 \\
\hline BMI9 & $21,96 \pm 1,16$ & 20,30 & $\begin{array}{c}24,20 \\
\text { *vsBMI9 }\end{array}$ \\
\hline
\end{tabular}

BM - pomiar masy ciała; MBF - zawartość tkanki tłuszczowej; FFM - wolna masa beztłuszczowa; MM - masa mięśniowa; TBW - całkowita ilość wody w organizmie; BMI - ciężar ciała; 1 - pomiar pierwszy; 9 - pomiar dziewiąty;

* istotność różnic na poziomie $p \leq 0,05$ 
do wartości uzyskiwanych dla FFM oraz MM. U 7 (50\% ) osób poprawa wyniosła odpowiednio 1,1 kg oraz 1,06 kg.

Zmiany istotne statystycznie odnosiły się jedynie do BM, TBW oraz BMI, dla których wartości uległy obniżeniu na poziomie $\mathrm{p} \leq 0,05$, co świadczyło o pozytywnym, zgodnym z planowanym wpływie przeprowadzonego treningu. Pozostałe zmiany nie były istotne statystycznie.

\section{DYSKUSJA}

Analiza składu ciała prowadzona była w celach diagnostycznych z powodzeniem zarówno w odniesieniu do oceny stanu odżywienia osób z nadwagą czy niedowagą i jego kontroli w przebiegu schorzeń lub procesie redukcji masy ciała, jak również wykorzystywana jest w sporcie do kontroli treningu sportowego, oceny stopnia przygotowania zawodników wielu dyscyplin sportowych. Staje się metodą coraz bardziej rozpowszechnioną i docenianą. Dzięki temu przybywa coraz więcej nowych narzędzi diagnostycznych, za pomocą których może być wykonana precyzyjnie analiza składu ciała w sposób nieinwazyjny, łatwo dostępny i stosunkowo niedrogi. Bioimpedancja elektryczna (BIA) jest metodą nowoczesną, jednak nie wolną od wad. Warunkiem rzetelnych pomiarów wśród sportowców, poza zachowaniem ogólnie przyjętych standardów procedury pomiarowej, jest uwzględnienie wielu czynników, które mogą modyfikować wyniki [6]. Według badań przeprowadzonych przez Segal [7], sportowcy bardzo często znajdują się w stanie „niekontrolowanym”, spowodowanym ciężkimi treningami, a w związku z tym odwodnieniem, zubożeniem zapasów glikogenu, przemęczeniem. Duży wpływ na wynik ma specyficzna dieta oraz intensywny trening. Należy jednak zwrócić uwagę, że są to także czynniki, które wskazują, jak ważne jest stałe kontrolowanie składu ciała zawodników $\mathrm{w}$ trakcie cyklu treningowego. $\mathrm{W}$ tym przypadku zawodnicy znajdowali się na zgrupowaniu kadry, na miesiąc przed głównymi zawodami sezonu. Ich dieta była planowana przez dietetyków, a zdrowie objęte opieką lekarzy i fizjoterapeutów. Jednym z zadań opieki fizjoterapeutycznej było monitorowanie składu ciała zawodników. Prezentowane badania odnoszą się do wpływu treningu na etapie przygotowania startowego na charakter zmian składu ciała. W rezultacie przeprowadzonych pomiarów na przestrzeni jednego miesiąca wykazano trend obniżania się wartości większości parametrów w cyklu 9 kolejnych pomiarów. Ciekawym zjawiskiem wydaje się być uzyskanie dla niemal wszystkich parametrów wartości najniższej w trakcie 7. dnia pomiarowego. Pomiar ostatniego dnia wykazał wzrost tych wartości względem pomiaru 7., lecz mimo wszystko wartości te były niższe od wyjściowych. Jak zauważono w badaniach Cieślickiej i wsp. [8], istnieje możliwość obniżania zawartości wybranych komponentów ciała (głównie tkanki tłuszczowej) bez współwystępowania obniżenia zawartości beztłuszczowej masy ciała, co jest zjawiskiem korzystnym i niezbędnym do utrzymania wysokiego poziomu przygotowania motorycznego zawodników. Dalsza redukcja masy ciała i spadek wskaźników tkanki tłuszczowej są niewskazane, choć należy pamiętać, że możliwe, ale poprzez redukcję masy tkanek beztłuszczowych lub poprzez obniżenie zawartości wody w ustroju. Niesie to jednak wysokie ryzyko utraty wydolności fizycznej oraz spadku siły, co wpływa negatywnie na wyniki sportowe.

Analiza statystyczna wyników uzyskanych w trakcie prowadzenia badań potwierdziła wpływ treningu na poprawę w zakresie 3 parametrów - BM, TBW, BMI. Można stwierdzić, że w wyniku treningu prowadzonego w trakcie okresu bezpośredniego przygotowania startowego (podczas badań trwających w tym przypadku 4 tyg.) zmianie uległy parametry składu ciała, których nie planowano i nie kierowano dietą oraz obciążeniami treningowymi w celu zajścia tych zmian. W przypadku pozostałych wskaźników - MBF, FFM, MM zmiany były statystycznie niezamienne. Istotne jest zwrócenie uwagi, że zmiany te były korzystne z punktu widzenia poprawy zdolności motorycznych pływaków i osiągania przez nich poprawy opływowości ciała oraz zdolności do kontroli poziomu jego zanurzenia, co przekłada się na zdolności szybkościowe podczas pływania.

Trening w czasie kolejnych tygodni okresu bezpośredniego przygotowania startowego jest związany z określonym rozkładem obciążeń wysiłkiem fizycznym. Trenerzy w tym modelu BPS stosowali obciążenia treningowe, gdzie przez pierwsze 2 tyg. następowało zwiększenie objętości, przy zmniejszonej intensywności wysiłku. Następne 2 tyg. charakteryzowały się zmniejszeniem objętości treningowej i zwiększeniem jego intensywności. Zejście z objętości we wszystkich okresach wynosiło $20 \%$ wartości względem poprzedniej. W trakcie ostatnich 2 tyg. nastąpiło kolejne zmniejszenie objętości, a czas treningowy był przeznaczony na trening szybkości oraz stosowanie ćwiczeń regenerujących - odbudowujących. Fakt ten może wyjaśniać osiągniętą w badaniach niewielką tendencję zwyżkową mającą miejsce po 7. czasie pomiarowym, który przypadł na 5. tydzień BPS-u. Charakter obserwowanych zmian w kierunku obniżania się tłuszczowych parametrów składu ciała był prawidłowy i oczekiwany. Nie pogorszyły one parametrów wzrostowo-wagowych, przez co przyczyniły się do uzyskiwania bardzo dobrych wyników sportowych.

Ponieważ BPS trwał 6 tyg., a badania dotyczyły ostatnich 4 tyg., należy zaznaczyć, że utrzymanie beztłuszczowych składników ciała na odpowiednim poziomie przez pierwsze 2 okresy zależne i możliwe było dzięki zastąpieniu dużej objętości treningowej (pierwsze 2 tyg.) przez dużą intensywność w okresie kolejnego etapu (2 tyg.). Najistotniejszą sprawą było utrzymanie składu ciała na niezmiennym lub nawet zniżkowym poziomie w okresie ostatnich 2 tyg., gdzie intensywność i objętość była bardzo mała. Okres ten charakteryzował się stosowaniem wysiłków o charakterze szybkościowym, przede wszystkim niekwasomlekowych, jak również ćwiczeniami regenerującymi.

W tym zakresie prowadzona jest niedostateczna ilość badań, dlatego zasadnym byłoby przeprowadzenie badań obejmujących dłuższy okres treningowy, zaczynając od okresu przygotowawczego, a kończąc na bezpośrednim przygotowaniu startowym. Na podstawie badań polskich olimpijczyków 
w kajakarstwie przeprowadzonych przez Klusiewicza i wsp. [9] wykazano, że samo utrzymanie parametrów na odpowiednim poziomie jest bardzo ważnym elementem sprzyjającym uzyskiwaniu dobrego wyniku. Wyniki badań potwierdziły jednocześnie, że osiągnięcie wysokich wyników przez kajakarzy nie byłoby możliwe bez zwiększenia masy mięśniowej, przy jednoczesnym spadku zawartości tkanki tłuszczowej do takiego poziomu, który nie zagrażał zdrowiu. Tezę tę popierają także badania własne, wg których najlepsi polscy juniorzy, przygotowujący się do najważniejszego startu w sezonie, potrafią utrzymać parametry składu ciała (MBF, FFM, MM) na nieznamiennym statystycznie poziomie. Dodatkowo można stwierdzić, że osiąganie najlepszych czasów startowych w pływaniu wiąże się ze zjawiskiem poprawy parametrów składu ciała (BM, TBW, BMI) w końcowym okresie bezpośredniego przygotowania startowego, co bardzo dobrze świadczy o doborze obciążeń treningowych oraz profesjonalnym zaangażowaniu zawodników. Pomimo specyfiki zmian w zakresie obciążeń treningowych okresu przedstartowego (zejścia z obciążeń treningowych), potrafią utrzymać parametry składu ciała na takim poziomie, który pozwala na osiąganie wysokich wyników sportowych.

\section{WNIOSKI}

1. W trakcie bezpośredniego przygotowania startowego w okresie miesięcznego zgrupowania poprzedzającego Mistrzostwa świata juniorów w Dubaju w 2013 r. została zachowana prawidłowa tendencja utrzymywania wskaźników masy ciała, pomimo spadku obciążeń treningowych.

2. Wyniki badań potwierdziły, że zawodnicy i trenerzy mają dobrze zaplanowany system przygotowań w odniesie- niu do doboru objętości i intensywności treningu oraz diety pływaków na poziomie szkolenia juniorów.

3. Kontrola komponentów składu ciała w trakcie całego cyklu treningowego ma duże znaczenia dla monitoringu przebiegu oraz wyników procesu treningowego i należałoby nimi objąć zawodników w różnych okresach szkoleniowych.

\section{PIŚMIENNICTWO}

1. Czabański B., Pawełko B.: Historia pływania, piłki wodnej i skoków do wody. In: Elementy teorii pływania. Ed. B. Czabański, M. Fiłon. AWF, Wrocław 1988.

2. Florkiewicz B., Zwierko T., Krzepota J., Łubkowska W., Troszczyński J.: Formy zajęć sportowych i rekreacyjnych oraz kierunki badań naukowych w obiekcie Floating Arena w Szczecinie. Zeszyty Naukowe Uniwersytetu Szczecińskiego, Ekonomiczne Problemy Usług. Sport i rekreacja szansą rozwoju regionu. 2011, 690 (79), 641-652.

3. Onoprijenko B.J.: Ispolzowaniemodelirowania dla isladowaniasoprotiwlenia wody dwiżeniu Pieła pławca. Teoria i Praktika, Moskwa 1979.

4. Bartkowiak E.: Pływanie sportowe. Centralny Ośrodek Sportu, Warszawa 1999, 13-80.

5. Łubkowska W., Troszczyński J.: Poziom tkanki tłuszczowej i masy mięśniowej u szczecińskich pływaków kadry olimpijskiej, narodowej i wojewódzkiej. Aktywność Ruchowa Ludzi w Różnym Wieku. 2011, 15, 447-456.

6. Pietraszewska J., Jakubowski W.: Use of different methods for testing morphological characteristics and evaluation of body tissue composition of swimmers. Cent Eur J Sport Sci Med. 2013, 3 (3), 33-41.

7. Segal K.S.: Use of bioelectrical impedance analysis measurements as an evaluation for particpating in sports. Am J Clin Nutr. 1996, 64, Suppl. 3 469-471.

8. Cieślicka M., Osińska N., Zukow W.: Impact of specialized kayaking training for the body construction and composition of kayakers. Wpływ specjalistycznego kajakarskiego treningu na budowę i skład ciała kajakarzy. J Health Sci. 2013, 3 (6), 7-18.

9. Klusiewicz A., Broniec J., Szczepańska B., Burkhard-Jagodzińska K.: Wydolność fizyczna i skład ciała mistrzów olimpijskich w wioślarstwie (dwójka podwójna wagi lekkiej) w 6-letnim okresie szkolenia. Sport Wyczynowy. 2002, 5-6, 449-467. 